\title{
ASAM ANAKARDAT DARI KULIT BIJI JAMBU METE (Anacardium occidentale L) YANG MEMPUNYAI AKTIVITAS SITOTOKSIK
}

\author{
Dewi Kusrini, Mahendra Ismardiyanto \\ Laboratorium Kimia Organik Jurusan Kimia \\ FMIPA Universitas Diponegoro Semarang 50275
}

\begin{abstract}
ABSTRAK
Telah dilakukan isolasi senyawa fenolat fraksi kloroform beserta uji aktivitasnya dari kulit biji jambu mete dengan metoda maserasi, kromatografi kolom serta rekristalisasi. Penentuan struktur molekul dari senyawa fenolat dilakukan dengan menginterpretasikan spektra UV, IR dan Massa. Hasil identifikasi dari fraksi kloroform diperoleh senyawa asam anakardat dengan $L C_{50}: 15,8489 \mathrm{ppm}$.

Kata kunci : Kulit biji jambu mete, asam anakardat, aktivitas.
\end{abstract}

\begin{abstract}
The Phenol compounds have been isolated of chloroform fraction and activity test from Cashew Nut Shell by maseration, columm chromatography and crystallization. The structure molecule identification of phenol compound was done by UV, IR and mass spectra. Results show that chloroform fraction has anacardad acid, with activity $L C_{50}: 15,8489 \mathrm{ppm}$. Key word: Cashew Nut Shell, Anacardad acid, activity
\end{abstract}

\section{PENDAHULUAN}

Jambu mete merupakan salah satu tanaman yang banyak digunakan sebagai obat tradisional Semua bagian tanaman ini mempunyai manfaat dan kasiat yang berbeda. (Hembing,1996).

Kulit batang jambu mete bisa digunakan sebagai bahan penyamak kulit atau obat penyembuh sariawan. Daun mudanya bisa dimakan sebagai lalapan. Daging buah semunya bisa dibuat manisan, selai atau dirujak. Air daging buah digunakan untuk bahan baku pembuatan anggur, cuka atau jelly. Sedangkan bijinya apabila telah diolah akan menghasilkan makanan yang bernilai ekonomis tinggi. Getah kulit biji jambu mete bila mengenai kulit kita, akan menyebabkan kulit terbakar. Dan kulit biji jambu mete banyak digunakan sebagai obat untuk borok dan penyakit menahum padla kulut. (Marlina, 1994)

Kulit biji jambu mete merupakan limbah pada pengolahan biji jambu mete yang terdapat disekitar $67 \%$ dari mete glondong. Limbah padat ini mengandung 32-37\% minyak yang dikenal sebagai minyak laka atau CNSL (Cashew Nut Shell Liquid). CNSL mengandung senyawa fenol alam terdiri dari asam anakardat, kardol, 2-metil kardol dan kardanol (Tyman, 1975). Senyawa fenol alam yang terkandung dalam kulit biji jambu mete mempunyai sifat khas, yang berperan dalam bidang industri, juga mempunyai sifat anti bakteri. (Himejima, 1991).

Dari penelitian diperoleh bahwa dari fraksi kloroform diperoleh senyawa fenolat yaitu asam anakardat berbentuk kristal putih yang berpotensi sebagai anti tumor.

\section{Percobaan.}

Umum. Pada penelitian ini: kromatografi kolom vakum dilakukan menggunakan silika gel(Merck) 60G dan analisis kromatografi lapis tipis (KLT) pada pelat aluminium yang berlapis silika gel $60 \mathrm{~F}_{254}$ (Merck, 30-70 mesh), kromatografi lapis tipis preparatif menggunakan pelat kaca berlapis silika gel $\mathrm{GF}_{254}$ (Merck, 200-400 mesh). Titik leleh ditentukan dengan menggunakan alat penetapan titik leleh mikro. Spektrum UV diukur dengan Spektrofotometer Ultraviolet Milton Roy Spectroline 3000 Arroy, spektrum IR diukur spektrofotometer Infrared Shimadzu FTIR 8201 PC dan spektrum Massa diukur dengan Gas Chromatography- Mass Spectrometry GCS HP $180^{\circ} \mathrm{C}$.

Pengumpulan Bahan.Sampel berupa kulit biji jambu mete diambil dari perkebunan jambu mete di daerah Wonogiri, Jawa-Tengah. 
Ekstraksi dan isolasi. Kulit biji jambu mete yang sudah kering digiling $(1 \mathrm{~kg})$ dimaserasi dengan menggunakan pelarut n-heksana, setelah pelarut diuapkan dengan tekanan rendah diperoleh ekstrak kasar n-heksana seba:yyak $35,5 \mathrm{~g}$ berupa cairan kental yang berwarna coklat. Residu dari ekstrak n-heksana dimaserasi kembali dengan menggunakan pelarut kloroform. Setelah pelarut diuapkan dengan tekanan rendah diperoleh ekstrak kloroform berwarna coklat. Pemisahan senyawa dilakukan dengan menggunakan kromatografi kolom vakum dengan eluen: $n$-heksana - kloroform - etil asetat:2:5:5. Dipilih fraksi yang ke 7 yang mengandung 4 senyawa ( $R f: 0,88 ; 0,76 ; 0,47$ dan 0,13 ). Terhadap fraksi ini dilakukan KLT preparatif dengan pengembang: n-heksana-kloroform-etil asetat : $1: 4: 2$ dan diambil noda pada Rf : 0,56 (dominan) selanjutnya dilarutkan dalam kloroform dan diuapkan. Hasil isolasi direkristalisasi dengan metanol panas diperoleh kristal putih berbentuk jarum. Uji kemurnian dari kristal hasil isolasi dengan pengembang : n-heksana (Rf: 0,0), kloroform (Rf: 0,37), etil asetat (Rf : 0,93) dan metanol (Rf: 0,81)

\section{Uji Aktivitas.}

Uji aktivitas dilakukan baik terhadap ekstrak kasar, fraksi hasil kolom maupun terhadap kristal hasil pemurnian dengan metoda "Brine Shrimp Lethality" dengan hewan uji yaitu larva Artemia salina yang digunakan berumur 1 hari.

\section{Data hasil percobaan}

Senyawa fenolat atau asam anakardat hasil isolasi dari ekstrak kloroform berupa kristal putih, memperlihatkan spektrum UV (kloroform) $\lambda_{\text {maks }} 232 \mathrm{~nm}$ dan 303 nm. Spektrum IR (KBr) $v_{\text {maks }}\left(\mathrm{cm}^{-1}\right) 3429,2(\mathrm{OH})$, 1660,6 ( $\mathrm{C}=\mathrm{O}$ keton), 1249,8 (C-O dari asam karboksilat), 3018,4 (C-H aromatik), 1211,2 - 1031,8 (C-H tekuk aromatik), 893 dan 759,9 (substitusi benzena), 2923,9 dan 2852,5 (C-H ulur dari $\mathrm{CH}_{2}$ dan $\mathrm{CH}_{3}$ ), 1463,9 dan 1377,1 (C-H tekuk dari $\mathrm{CH}_{2}$ dan $\mathrm{CH}_{3}$ ). GC-MS m/z: $\mathrm{M}^{+}$(348), 221, 137, 133, 119, 85, 75, 71, 57 dan 45.

Aktivitas Zat $\left(\mathrm{LC}_{50}\right)$

\begin{tabular}{|c|c|c|c|}
\hline Fraksi & $\begin{array}{c}\text { Ekstrak kasar } \\
\mathrm{LC}_{50}(\mathrm{ppm})\end{array}$ & $\begin{array}{c}\text { Hasil kolom } \\
\mathrm{LC}_{50}(\mathrm{ppm})\end{array}$ & $\begin{array}{c}\text { Kristal murni } \\
\mathrm{LC}_{50}(\mathrm{ppm})\end{array}$ \\
\hline & & & \\
\hline Kloroform & $1,106210^{-5}$ & 0,468631 & 15,8489 \\
\hline
\end{tabular}

\section{Pembahasan}

Pada ekstrak kloroform kulit biji jambu mete telah ditemukan satu senyawa fenolat. Senyawa ini diperoleh melalui beberapa tahap pemisahan, diikuti pemilihan fraksi berdasarkan analisis kromatografi lapis tipis dan kromatografi kolom vakum .

Senyawa fenolat atau asam anakardat diperoleh sebagai kristal putih. Spektrum UV, menunjukkan $\lambda_{\text {maks }}$ (kloroform) pada $232 \mathrm{~nm}$ dan $303 \mathrm{~nm}$, dimana pada $\lambda_{\text {maks }} 232 \mathrm{~nm}$ dan $303 \mathrm{~nm}$ berasal dari transisi $\mathrm{n} \rightarrow \pi^{*}$ dan transisi $\pi \rightarrow \pi^{*}$ (terkonjugasi). Hal ini menunjukkan bahwa senyawa murni hasil isolasi mempunyai kromofor-kromofor yang mempunyai elektron bebas dan ikatan rangkap terkonjugasi.

Dari spektrum IR memperlihatkan bilangan gelombang pada $3429,2 \mathrm{~cm}^{-1}$ menunjukkan adanya gugus $\mathrm{OH}$, serapan pada $3018,4 \mathrm{~cm}^{-1}$ (C-H ulur dari Aromatik), adanya benzena diperkuat pada $1505,4 \mathrm{~cm}^{-1}$ $(\mathrm{C}=\mathrm{C})$ dan serapan $1211,2-1031,8 \mathrm{~cm}^{-1}$ (vibrasi tekuk Ar-H di dalam bidang) dan serapan 893,0$759,9 \mathrm{~cm}^{-1}$ adanya substitusi pada benzena. Serapan pada panjang gelombang 2923,9 dan $2852,5 \mathrm{~cm}^{-1}$ (C-H ulur dari $\mathrm{CH}_{2}$ dan $\mathrm{CH}_{3}$ ) diperkuat serapan pada 1463,9 dan $1377,1 \mathrm{~cm}^{-1}$ adanya $\mathrm{C}-\mathrm{H}$ tekuk dari $\mathrm{CH}_{2}$ dan $\mathrm{CH}_{3}$. Adanya gugus $\mathrm{C}=\mathrm{O}$ ditunjukkan pada serapan $1660,6 \mathrm{~cm}^{-1}$ yang diperkuat serapan pada $1249,8 \mathrm{~cm}^{-1}$ menunjukkan adanya $\mathrm{C}-\mathrm{O}$ dari asam karboksilat. (Silverstein,1991)

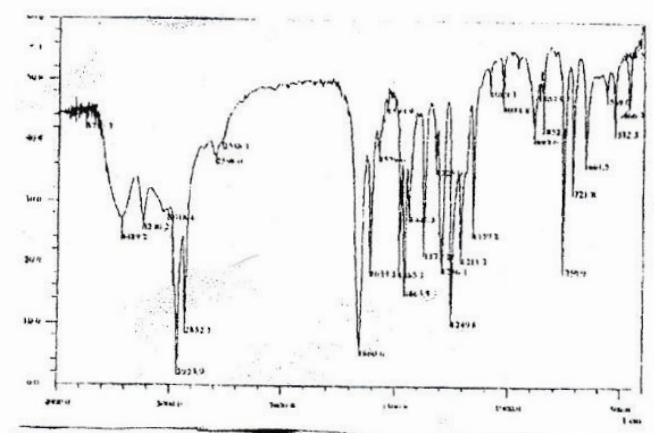

Gambar 1. Spektrum IK darı senyawa murni fraksi kloroform.

Analisis dengan spektroskopi massa menggunakan GC- MS GCD HP 1800 C menghasilkan pola-pola fragmentasi dengan ion molekul pada harga $\mathrm{m} / \mathrm{z}$ sebesar 348, ini menunjukkan bahwa senyawa terisolasi mempunyai berat molekul sebesar 348 . Fragmentasi yang keluar adalah: 221, 137, 133, $119,85,75,71,57$ dan 45 . 


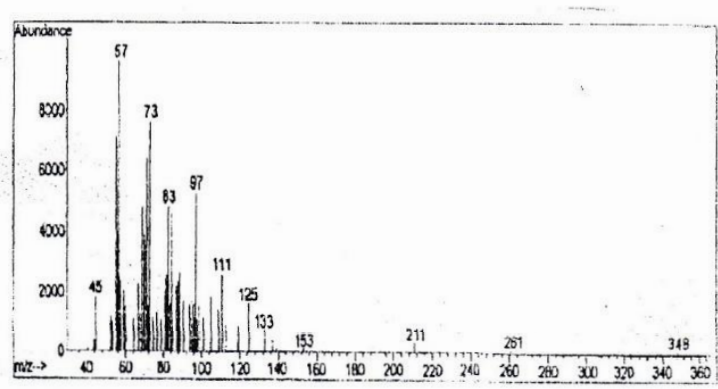

Gambar 2. Spektrum Massa dari senyawa murni fraksi kloroform.

Dari penggabungan analisis UV, IR dan MS bahwa senyawa murni mengandung gugus $\mathrm{OH}$, benzena, asam karboksilat, rantai alifatik dan $\mathrm{M}^{+}: 348$ maka dapat diketahui bahwa senyawa murni adalah: asam anakardat dengan struktur dan fragmentasinya sebagai berikut:

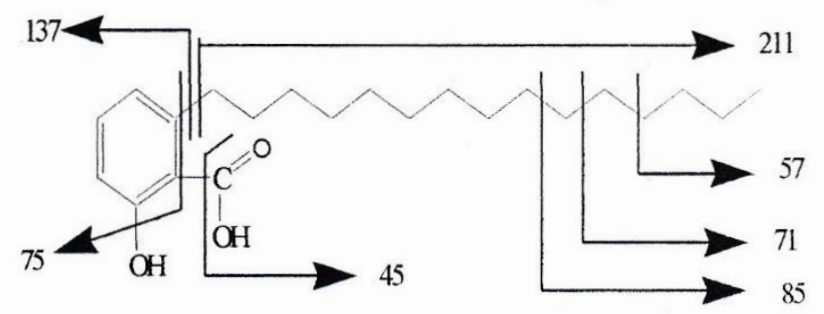

riii aktivitas dilakukan baik terhadap ekstrak kasar, 77 ksi 7 hasil kolom dan kristal hasil isolasi dengan metoda "Brine Shrimp Lethality". Dari uji yang dilakukan maka diperoleh LC $_{50}$ ekstrak kasar $1,106210^{-5}$ ppm, fraksi 7 hasil kolom : 0,468631 ppm dan kristal murni : 15,8489 ppm. Menurut Meyer (1982), dengan menggunakan metoda "Brine Shrimp Lethality" diketahui bahwa senyawa yang mempunyai $\mathrm{LC}_{50}<30 \mathrm{ppm}$ bersifat sitotoksik, $\mathrm{LC}_{50} 30-200 \mathrm{ppm}$ bersifat anti mikroba dan $\mathrm{LC}_{50}>200 \mathrm{ppm}$ bersifat pestisida. Dengan membandingkan harga LC50 senyawa murni hasil isolasi dengan penelitian Meyer dapat diketahui bahwa kristal hasil isolasi ( asam anakardat) mempunyai potensi sebagai zat anti kanker/ tumor.

\section{Kesimpulan.}

Dari penelitian yang telah dilakukan terhadap fraksi kloroform kulit biji jambu mete diperoleh hasil, satu senyawa fenolat atau asam anakardat yang berbentuk kristal putih yang berpotensi sebagai anti tumor/kanker.

\section{Pustaka}

1. Hembing Wijayakusuma; 1996, Tanaman Berkhasiat Oúat di Indonesia, jilid 3, Pustaka Kartini, Indonesia
2. Himejima, M; Kubo, I; 1991, Antibacterial Agent from the Cashew Anacardium occidentale L (Anacardiaceae) Nut Shell Oil, J. Agriculture Food Chemistry, Vol. IX, p 418-421.

3. Meyer, B. N; Ferrigi, N.R; 1982, Brine Shrimp A Convennient General Bioassays for Active Plant Contituent, Plant Medical, vol 45 (31-34)

4. Marlina, N. J; 1994, Jambu Mete dan Pembudidayaannya, Penerbit Kanisius, Jogyakarta.

5. Silverstein, R.M, and Bassler,G.C; 1991, Spectrometric Identification of Organic Compounds, $5^{\text {th }} \mathrm{Ed}$, John Willey \& Sons, Inc. Singapore.

6. Tyman,J.H.P; 1975, Quantitative Determination of the Olefinic Composision of the Component Phenols in Cashew Nut Shell Liquid. J.Chrom, Vol. 3. P 277-284. 